\title{
PENGETAHUAN PERAWAT TENTANG PENCEGAHAN LIMFEDEMA PADA PASIEN POST MASTEKTOMI DI RSUD ARIFIN ACHMAD PROVINSI RIAU
}

\author{
Cahya Rifta Yani, Rani Lisa Indra, Bayu Saputra
}

PSIK STIKes Hang Tuah Pekanbaru, Jl. Mustafa Sari No. 5 Tangkerang Selatan, Pekanbaru. Email: cry060311@gmail.com

\begin{abstract}
Abstrak
Limfedema adalah pembengkakan lengan dalam jaringan subkutan dan merupakan komplikasi post mastektomi yang disertai dengan pengangkatan nodus limfe aksilaris. Walaupun tidak mengancam nyawa, namun berdampak negatif pada kualitas hidup survivor kanker payudara. Penelitian ini bertujuan untuk mengetahui gambaran pengetahuan perawat tentang pencegahan limfedema pada pasien post mastektomi di RSUD Arifin Achmad Provinsi Riau. Penelitian ini merupakan penelitian deskriptif kuantitatif, dengan sampel 36 perawat yang bekerja di ruang rawat inap surgical yang diambil secara consecutive sampling. Pengumpulan data menggunakan kuesioner yang diolah secara univariat menggunakan tendensi sentral dan distribusi frekuensi. Hasil penelitian menunjukkan rata-rata responden berusia 31 tahun dengan lama bekerja 42,42 bulan, $75 \%$ responden berjenis kelamin perempuan, $50 \%$ responden dengan tingkat pendidikan DIII keperawatan, dan sebanyak $72,2 \%$ respon tidak pernah mengikuti pelatihan tenteng perawatan post mastektomi. Pengetahuan perawat tentang pencegahan limfedema post mastektomi berada pada kategori cukup. Kepada perawat diharapkan untuk lebih meningkatkan lagi pengetahuannya tentang perawatan post mastektomi untuk mencegah terjadinya limfedema salah satunya dengan mengikuti seminar/pelatihan dan melanjutkan jenjang pendidikannya.
\end{abstract}

Kata kunci: Limfedema, Mastektomi, Pengetahuan

\begin{abstract}
Lymphedema is a swelling of the arms in the subcutaneous tissue and it is a postmastectomy complication accompanied by removal of axillary lymph nodes. Although not life-threatening, but a negative impact on the quality of life of breast cancer survivors. The purpose of this study was to determine the nurse knowledge about prevention of lymphedema in post-mastectomy patient at RSUD Arifin Achmad Riau Province. This study was a quantitative descriptive study, with 36 nurses that working in a surgical inpatient room as samples that taken by consecutive sampling. The data collection used a questionnaire and processed in univariate analysis using central tendency and frequency distribution. The results showed that the average respondent age was 31 years old with 42,42 months of working periode, $75 \%$ of respondents were female, $50 \%$ of respondents had level education in diploma of nursing, and $72.2 \%$ of respondents never participated in post-mastectomy care training. The nurse's knowledge of preventing post-mastectomy lymphedema is in the sufficient category. The nurses are expected to further improve their knowledge about postmastectomy care to prevent lymphedema, one of them by attending seminar/training and continuing education level.
\end{abstract}

Key words : Knowledge, Lymphedema, Mastecto 


\section{PENDAHULUAN}

Kanker payudara merupakan suatu keganasan akibat pertumbuhan sel abnormal pada jaringan payudara (Kemenkes, 2013). Data Global Burden of Cancer (GLOBOCAN) dan International Agency for Research on Cancer (IARC) tahun 2012 menunjukkan bahwa kanker payudara merupakan salah satu jenis kanker yang paling sering didiagnosis dengan persentase kematian dan kasus baru tertinggi yaitu sebesar $12,9 \%$ dan 43,3\% (Ferlay et al., 2015).

Estimasi jumlah penderita kanker payudara di Indonesia pada tahun 2013 yaitu sebanyak 61.682 penderita (Kemenkes, 2015). Data Sistem Informasi Rumah Sakit (SIRS) tahun 2007 menunjukkan kejadian kanker payudara menempati urutan pertama dengan kasus pasien rawat inap sebanyak $16,85 \%$ dan kasus pasien rawat jalan 21,69\% (Kemenkes, 2013). Data rekam medis RSUD Arifin Achmad Provinsi Riau menunjukkan bahwa kejadian kanker payudara pada tahun 2014 yaitu sebanyak 586 pasien dan menurun menjadi 219 pasien pada tahun 2015. Terhitung tanggal 1 Januari sampai 30 November 2016, kejadian kanker payudara mengalami peningkatan sebanyak 1062 pasien.

Mastektomi merupakan terapi pembedahan yang masih menjadi modalitas utama dalam pengobatan kanker payudara. Sebuah tinjauan sistematis yang meneliti komplikasi pada ekstremitas atas setelah dilakukan operasi kanker payudara, ditemukan limfedema sebesar 0\% sampai 34\% (Lee, Kilbreath, Refshauge, Herbert, \& Beith, 2008). Limfedema berdampak negatif pada kualitas hidup survivor kanker payudara yang dapat menyebabkan hilangnya fungsi tubuh secara permanen seperti penurunan rentang gerak yang menghambat aktifitas harian (DiSipio, Rye, Newman, \& Hayes, 2013).

Penelitian yang dilakukan oleh DiSipio et al (2013), menunjukkan bahwa kejadian limfedema meningkat 12 sampai $<24$ bulan setelah operasi kanker payudara. Menurut Setiyawati (2013), pasien post mastektomi tidak akan mengalami limfedema bila pasien diberikan pendidikan kesehatan.

Hasil penelitian Siwu, Savitri, dan Hutasoit (2014), menunjukkan adanya pengaruh pendidikan kesehatan yang diberikan terhadap tingkat pengetahuan klien tentang perawatan pascaoperasi kanker payudara. Penelitian tersebut juga menemukan bahwa tingkat pengetahuan klien dipengaruhi oleh tinggi rendahnya usia, pendidikan, pekerjaaan seseorang dan informasi yang diperoleh dari petugas kesehatan.

Perawat merupakan salah satu petugas kesehatan yang mempunyai kontribusi besar dalam meningkatkan pelayanan kesehatan dan mempunyai waktu terlama dalam berinteraksi dengan pasien dan keluarga. Peran perawat sebagai caregiver dan educator sangat penting dalam kegiatan discharge planning (perencanaan pulang) pasien yang akan mempengaruhi keberlanjutan perawatan mandiri oleh pasien di rumah (Potter \& Perry, 2005).

Hasil diskusi dengan perawat di ruang rawat inap surgical RSUD Arifin Achmad Provinsi Riau memberikan gambaran bahwa sebagian perawat tidak mengetahui limfedema merupakan komplikasi dari post mastektomi. Discharge planning yang dilakukan 
sebagian perawat juga belum optimal yaitu berupa informasi perawatan luka, asupan nutrisi, dan hanya menganjurkan pasien menggerakan lengan sisi pembedahan tanpa latihan yang struktur. Selain itu, perawat juga tidak menyampaikan kepada pasien post mastektomi mengenai aktivitas yang boleh dilakukan dan tidak boleh dilakukan setelah operasi yang dapat mencegah terjadinya limfedema. Hal ini mendasari peneliti untuk melakukan penelitian yang bertujuan untuk mengetahui tingkat pengetahuan perawat tentang pencegahan limfedema pada pasien post mastektomi.

\section{METODOLOGI PENELITIAN}

Penelitian ini merupakan penelitian deskriptif kuantitatif yang dilakukan di RSUD Arifin Achmad Provinsi Riau pada bulan Juni 2017. Sampel penelitian berjumlah 36 perawat yang bekerja di ruang rawat inap surgical kelas 2 dan kelas 3. Teknik pengambilan sampel secara consecutive sampling. Instrumen penelitian menggunakan kuesioner. Analisis data dilakukan univariat dalam bentuk distribusi frekuensi dan tendensi sentral.

\section{HASIL}

Responden penelitian ini sebagian besar berjenis kelamin perempuan ( 7 orang (75,0\%), tingkat pendidikan terbanyak DIII Keperawatan sebanyak 18 orang (50\%) dan, sebagian besar perawat tidak pernah mengikuti pelatihan terkait perawatan post mastektomi sebanyak 26 orang $(72,2 \%)$. Lihat tabel 1

\section{Tabel 1.}

Distribusi Frekuensi Karakteristik Perawat Berdasarkan Jenis Kelamin, Pendidikan dan Pelatihan

\begin{tabular}{lcc}
\hline Karakteristik Responden & $\mathrm{f}$ & $\%$ \\
\hline Jenis Kelamin & & \\
$\quad$ Laki-Laki & 9 & 25,0 \\
Perempuan & 27 & 75,0 \\
\hline Pendidikan & & \\
$\quad$ DIII Keperawatan & 18 & 50,0 \\
S1 Keperawatan & 10 & 27,8 \\
$\quad$ Ners & 8 & 22,2 \\
\hline Pelatihan & & \\
$\quad$ Pernah mengikuti & 10 & 27,8 \\
Tidak pernah & 26 & 72,2 \\
mengikuti & & \\
\hline \multicolumn{1}{c}{ Jumlah } & 36 & 100 \\
\hline
\end{tabular}

Tabel 2.

Distribusi Karakteristik Perawat

Berdasarkan Usia dan Lama Bekerja

\begin{tabular}{lccc}
\hline $\begin{array}{l}\text { Variabe } \\
1\end{array}$ & $\begin{array}{c}\text { Mean } \pm \\
\text { SD }\end{array}$ & Median & $\begin{array}{c}\text { Min }- \\
\text { Max }\end{array}$ \\
\hline Usia & $31,31 \pm$ & 30 & $26-$ \\
Perawat & 4,35 & & 40 \\
Lama & $42,42 \pm$ & 36 & $3-$ \\
Bekerja & 33,06 & & 132 \\
\hline
\end{tabular}

Tabel 2 menunjukkan rata-rata usia perawat adalah 31,31 tahun dengan standar deviasi 4,35 tahun, usia termuda 26 tahun dan tertua 40 tahun. Rata-rata perawat telah bekerja selama 42,42 bulan $(3,5$ tahun), dengan lama bekerja paling singkat adalah 3 bulan dan lama bekerja paling lama adalah 132 bulan (11 tahun). 
Tabel 3.

Distribusi Tingkat Pengetahuan Perawat tentang Pencegahan Limfedema pada

Pasien Post Mastektomi

\begin{tabular}{lcc}
\hline \multicolumn{1}{c}{$\begin{array}{c}\text { Tingkat } \\
\text { Pengetahuan }\end{array}$} & $\mathrm{f}$ & $\%$ \\
\hline Baik & 5 & 13,9 \\
Cukup & 27 & 75,0 \\
Kurang & 4 & 11,1 \\
\hline \multicolumn{1}{c}{ Jumlah } & 36 & 100 \\
\hline
\end{tabular}

Berdasarkan tabel 3 terlihat sebagian besar perawat memiliki tingkat pengetahuan yang cukup tentang pencegahan limfedema pada pasien post mastektomi.

\section{PEMBAHASAN}

Karakteristik Responden Jenis Kelamin

Hasil penelitian ini menggambarkan sebagian besar responden berjenis kelamin perempuan $(75 \%)$. Hasil penelitian ini memiliki kesamaan dengan penelitian yang dilakukan oleh Bawelle, Sinolungan dan Hamel (2013) bahwa jenis kelamin perawat didominasi oleh perempuan, karena dalam sejarahnya keperawatan muncul sebagai peran care taking (pemberi perawatan).

Sehubungan dengan halnya pengetahuan, jenis kelamin tidak termasuk dalam faktor yang mempengaruhi pengetahuan (Mubarak, 2007). Penelitian yang dilakukan oleh Ramanda dan Waluyo (2014), menunjukkan tidak ada perbedaan yang signifikan antara tingkat pengetahuan perawat dengan jenis kelamin, baik itu dalam kemampuan pemecahan masalah, keterampilan analisis, dorongan kompetitif, motivasi, kemampuan sosial dan kemampuan belajar.

\section{Usia}

Hasil penelitian yang diperoleh menunjukkan bahwa rata-rata usia perawat adalah 31 tahun dengan usia termuda 26 tahun dan usia tertua 40 tahun. Karakteristik usia perawat dalam penelitian ini berada pada rentang usia 2040 tahun yang berarti usia dewasa muda (Nasir \& Muhith, 2011).

Individu yang berada pada usia ini dituntut untuk menjalankan peran baru di tempat kerja, rumah, dan masyarakat, serta mengembangkan minat, nilai-nilai, dan sikap yang terkait dengan peran tersebut. Individu yang berada pada tahap ini memiliki tingkat kematangan dan kemampuan yang lebih dalam berpikir dan bekerja. Oleh karena itu, usia perawat sangat berpengaruh terhadap kinerja perawat dalam praktik keperawatan (Wahyudi, Iwan, Dewi, \& Sigit, 2010).

\section{Pendidikan}

Hasil penelitian menunjukkan persentase tertinggi pada jenjang pendidikan perawat adalah DIII Keperawatan sebanyak 18 orang (50\%). Pengetahuan erat kaitannya dengan pendidikan, dengan pendidikan yang tinggi maka individu tersebut akan semakin luas pengetahuannya (Wawan \& Dewi, 2010).

Penelitian yang dilakukan oleh Girsang dan Hasrul (2015) menunjukkan bahwa pendidikan perawat mempengaruhi tindakan keperawatan yang dilakukan. Perawat yang memiliki pendidikan tinggi akan dapat melaksanakan praktik keperawatan sesuai standar operasional prosedur yang ada dengan baik dibandingkan dengan perawat yang memiliki pendidikan rendah. 
Lama Bekerja

Hasil penelitian yang telah dilakukan didapatkan bahwa rata-rata lama bekerja perawat terbanyak adalah 42,42 bulan (3,5 tahun), dengan lama bekerja paling singkat adalah 3 bulan dan lama bekerja paling lama adalah 132 bulan (11 tahun). Menurut Rosyidah, Haryono, dan Oktafiani (2008), lama bekerja biasanya dikaitkan dengan waktu mulai bekerja, dimana pengalaman kerja juga ikut menentukan kinerja seseorang. Semakin lama masa kerja maka kecakapan akan lebih baik karena sudah menyesuaikan diri dengan pekerjannya.

Christensen dan Kenney (2009) mengemukakan bahwa semakin banyak pengalaman, semakin bertambah pengetahuan perawat tentang diri mereka sendiri, kesehatan klien, kemampuan untuk menginterpretasikan informasi tertentu dan melakukan tindakan keperawatan.

\section{Pelatihan}

Hasil penelitian yang telah dilakukan terhadap 36 perawat didapatkan bahwa sebagian besar perawat tidak pernah mengikuti pelatihan terkait perawatan post mastektomi yaitu sebanyak 26 orang (72,2\%). Menurut Simamora (2006), pelatihan merupakan suatu proses pembelajaran yang dirancang untuk meningkatkan keahlian, pengetahuan, dan pengalaman yang akan menghasilkan suatu perubahan perilaku yang spesifik bagi karyawan atau pegawai.

Hasil penelitian yang dilakukan oleh Yulia, Hamid dan Mustikasari (2012) membuktikan bahwa pelatihan dapat meningkatkan pemahaman perawat pelaksana yang dipengaruhi perubahan kognitif selama proses pelatihan.
Kemampuan kognitif mempengaruhi kemampuan individu dalam melakukan tindakan yang tidak menimbulkan risiko terhadap keselamatan pasien. Pelatihan keperawatan sangat penting dan perlu dilakukan secara rutin, karena pelatihan merupakan salah satu bentuk pengembangan perawat untuk keberhasilan kinerja dan kemajuan suatu institusi rumah sakit.

\section{Pengetahuan Perawat tentang Pencegahan Limfedema pada Pasien Post Mastektomi}

Hasil penelitian yang telah dilakukan diketahui bahwa tingkat pengetahuan perawat berada dalam kategori cukup tentang pencegahan limfedema post mastektomi. Menurut pendapat Arikunto (2006) dalam Wawan dan Dewi (2010), bahwa tingkat pengetahuan yang cukup adalah tingkat pengetahuan dimana seseorang mampu mengetahui dan memahami, tetapi kurang mengaplikasi, menganalisis, mensintesis dan mengevaluasi.

Berdasarkan teori tersebut dan hasil kuesioner yang telah disebar pada 36 perawat menunjukkan bahwa sebagian besar perawat tahu dan memahami secara teori terkait pencegahan limfedema post mastektomi, tetapi belum tahu dan memahami secara aplikasi atau tindakan yang dapat dilakukan untuk mencegah limfedema tersebut.

Penelitian yang dilakukan oleh Girsang dan Hasrul (2015) bahwa perawat yang lebih lama bekerja tidak selalu mempunyai keterampilan lebih baik terhadap suatu tindakan keperawatan akibat dari proses pengulangan dalam melakukan tindakan. Lama kerja tidak mempengaruhi perawat untuk melakukan 
suatu tindakan seperti halnya dalam melakukan pencegahan limfedema post mastektomi, karena ada faktor lain yang lebih berpengaruh terhadap tindakan tersebut seperti pengetahuan yang didapatkan perawat melalui jenjang pendidikan yang lebih tinggi, seminar dan pelatihan yang diikuti oleh perawat.

Berdasarkan hasil penelitian ini diketahui bahwa belum semua perawat mendapatkan pelatihan terkait perawatan post mastektomi, sehingga faktor ini dapat menyebabkan tingkat pengetahuan perawat tergolong dalam kategori cukup. Pengetahuan dan keterampilan yang dimiliki perawat dapat mempengaruhi perilaku perawat tersebut yang berdampak pada kualitas layanan keperawatan yang dilakukan.

Selain itu, tingkat pengetahuan perawat yang cukup juga dapat dikarenakan perbedaan tingkat pendidikan yang dimiliki oleh perawat. Pendidikan merupakan suatu faktor yang menentukan dalam mendapatkan pengetahuan. Pengetahuan seorang perawat bervariasi tergantung tingkat pendidikan yang dimiliki. Hal ini berkaitan dengan perkembangan dari ilmu keperawatan, kedalaman dan luasnya ilmu pengetahuan akan mempengaruhi kemampuan perawat untuk berpikir kritis dalam melakukan tindakan keperawatan (Saifullah, 2015).

Semakin tinggi tingkat pendidikan maka pemahamannya terhadap informasi menjadi semakin baik. Selain itu tingkat pendidikan yang semakin tinggi, akan semakin baik pula pola pikirnya. Pola pikir yang baik akan menyebabkan seseorang mempunyai kemampuan dalam hal analisis yang lebih baik (Saifullah, 2015). Hal ini sesuai dengan teori Effendi dan Makhfudli (2009) yang mengatakan pengetahuan merupakan domain yang sangat penting untuk terbentuknya tindakan seseorang, sebab perilaku yang didasari oleh pengetahuan dan kesadaran akan lebih baik daripada perilaku yang tidak didasari oleh pengetahuan dan kesadaran, maka perilaku tersebut tidak akan berlangsung lama.

Nursalam (2008) menyebutkan bahwa sebagai perawat professional harus memiliki peran education yang artinya dalam upaya meningkatkan kualitas layanan keperawatan, perawat harus mempunyai komitmen yang tinggi terhadap profesi dengan secara kontinu menambah ilmu pengetahuan melalui pendidikan formal maupun nonformal. Penelitian Hapsari (2013) menunjukkan bahwa terdapat hubungan peran perawat sebagai educator dengan pemenuhan kebutuhan rasa aman pasien di ruang rawat inap Rumah Sakit Umum dr. H. Koesnadi Bondowoso. Perawat sebagai petugas kesehatan yang akan menyampaikan pesan pada pasien harus mempunyai pengetahuan yang memadai untuk membantu perawat dalam menyampaikan informasi kepada pasien. Menurut Kozier dan Erb's (2008), informasi yang spesifik sangat dibutuhkan pasien demi keamanan dan keselamatannya. Pencegahan merupakan salah satu karakteristik dari keamanan yang dapat dilakukan dengan pemberian informasi oleh perawat.

Hal tersebut sejalan dengan penelitian ini, dimana pencegahan limfedema post mastektomi berkaitan dengan peran perawat sebagai educator yang menjadi bagian dalam pelaksanaan discharge planning (perencanaan pulang). Penelitian yang dilakukan Pertiwiwati dan Rizany (2016) menunjukkan bahwa ada hubungan antara peran educator perawat 
dengan pelaksanaan discharge planning di RSUD Ulin Banjarmasin.

Menurut Potter dan Perry (2005), discharge planning (perencanaan pulang) merupakan serangkaian kegiatan yang terlibat dalam pemberian asuhan keperawatan yang berkesinambungan dan terkoordinasi ketika pasien dipulangkan dari rumah sakit. Perawat mempunyai tanggung jawab dalam memberi instruksi kepada pasien tentang sifat masalah kesehatan, hal-hal yang harus dihindari, penggunaan obat-obatan di rumah, jenis komplikasi dan sumber bantuan yang tersedia.

Berdasarkan penelitian dan teori diatas, peneliti berasumsi bahwa pelaksanaan discharge planning yang tidak optimal dapat berdampak pada pasien/keluarga ketika melakukan perawatan kesehatan dirumah. Pasien/keluarga yang belum mampu untuk melakukan perawatan secara mandiri akan kembali dengan kondisi kekambuhan, timbulnya komplikasi penyakit, dan kemungkinan pasien untuk dirawat kembali yang tentunya akan sangat merugikan pasien dan keluarga. Penelitian yang dilakukan oleh Hariyati, Afifah, dan Handiyani (2008) menunjukkan bahwa discharge planning (perencanaan pulang) sangat membantu pasien dan kelurga dalam mempersiapkan pulang, dimana persiapan pulang mempunyai dampak terhadap kesiapan adaptasi dan koping terhadap stress, sehingga meningkatkan kepuasan dan kualitas hidup pasien.

\section{KESIMPULAN}

Tingkat pengetahuan perawat tentang pencegahan limfedema pada pasien post mastektomi di RSUD Arifin
Achmad Provinsi Riau berada dalam kategori cukup.

\section{SARAN}

Oleh karena itu, disarankan kepada institusi pelayanan kesehatan agar dapat mengambil kebijakan dalam pelaksanaan seminar dan pelatihan terkait perawatan post mastektomi. Selain itu, tenaga keperawatan diharapkan dapat meningkatkan pengetahuan dalam melakukan tindakan keperawatan post mastektomi dengan melanjutkan pendidikan dan mengikuti pelatihan.

\section{DAFTAR PUSTAKA}

Bawelle, S.C., Sinolungan, J.S., \& Hamel, R.S. (2013). Hubungan pengetahuan dan sikap perawat dengan pelaksanaan keselamatan pasien (patient safety) diruang rawat inap RSUD Liun Kendage Tahuna. Jurnal Keperawatan. 1 (1). Universitas Sam Ratulangi Manado. Diperoleh dari http://ejournal.unsrat.ac.id

Christensen, P.J., \& Kenney, J.W. (2009). Proses keperawatan: Aplikasi model konseptual. (Ed.4). Jakarta : EGC.

DiSipio, T., Rye, S., Newman, B., \& Hayes, S. (2013). Incidence of unilateral arm lymphedema after breast cancer: A systematic review and meta-analysis. Lancet Oncology, 14 : 500-515. Diperoleh dari http://dx.doi.org/10.1016/S14702045(13)70076-7

Efendi, F \& Makhfudli. (2009). Keperawatan kesehatan komunitas: Teori dan praktik dalam keperawatan. Jakarta : Salemba Medika. 
Ferlay, J., Soerjomataram, I., Dikshit, R., Eser, S., Mathers, C., Rebelo, M., ... Bray, F. (2015). Cancer incidence and mortality worldwide : Sources, methods and major patterns in GLOBOCAN 2012. International Journal of Cancer, 136 : 359-386. DOI: 10.1002/ijc.29210

Girsang, B.M., \& Hasrul. (2015). Gambaran persiapan perawatan fisik dan mental pada pasien pre operasi kanker payudara. Jurnal Keperawatan Sriwijaya, 2 (1), 6476. Universitas Sriwijaya. Diperoleh dari http://unsri.ac.id

Hapsari, R.W. (2013). Hubungan peran perawat sebagai educator dengan pemenuhan kebutuhan rasa aman pasien di ruang rawat inap rumah sakit umum dr.H. Koesnadi Kabupaten Bondowoso. Skripsi Terpublikasi. Universitas Jember. Diperoleh dari http://repository.unej.ac.id

Hariyati, T.S., Afifah, E., \& Handiyani, H. (2008). Evaluasi model perencanaan pulang yang berbasis teknologi informasi. Makara Kesehatan, 12 (2), 53-58. Universitas Indonesia. Diperoleh dari http://repository.ui.ac.id

Kementerian Kesehatan RI. (2013). Pedoman teknis pengendalian kanker payudara dan kanker leher rahim. Jakarta : Direktorat Pengendalian Penyakit Tidak Menular.

Kementerian Kesehatan RI. (2015). Info datin : Stop kanker. Jakarta : Pusat Data dan Informasi Kementerian Kesehatan RI.

Kozier \& Erb's. (2008). Fundamentals of nursing concepts, process and practice. New Jersey : Pearson Education.

Lee, T.S., Kilbreath, S. L., Refshauge, K.M., Herbert, R.D., \& Beith, J.M. (2008). Prognosis of the upper limb following surgery and radiation for breast cancer. Breast Cancer Research and Treatment, 110 (1): 19-37. DOI: 10.1007/s10549-0079710-9

Mubarak \& Chayatin. (2011). Ilmu keperawatan komunitas (Jilid 1). Jakarta : Salemba Medika.

Nasir, A., \& Muhith, A. (2011). Dasardasar keperawatan jiwa pengantar dan teori. Jakarta : Salemba Medika.

Nursalam. (2008). Pendidikan dalam keperawatan. Jakarta : Salemba Medika.

Pertiwiwati, E. \& Rizany, I. (2016). Peran educator perawat dengan pelaksanaan discharge planning pada pasien di ruang tulip 1C RSUD Ulin Banjarmasin. Dunia Keperawatan. 4 (2), 82-87. Universitas Lambung Mangkurat.

Potter, P.A. \& Perry, A.G. (2005). Buku ajar fundamental keperawatan : Konsep, proses dan praktik (Ed.4). Jakarta : EGC.

Ramanda, F.A., \& Waluyo, A. (2014). Gambaran tingkat pengetahuan perawat terhadap HIV. Skripsi Terpublikasi. Fakultas Ilmu Keperawatan Universitas Indonesia. Rosyidah, Haryono, dan Oktafiani, R. (2008). Hubungan karakteristik perawat dengan kinerja perawat dalam menangani ODHA di RS PKU Muhammadiyah Yogyakarta. Jurnal Kesehatan Masyarakat. 2 (3),181-191. Universitas Ahmad Dahlan Yogyakarta. 
Saifullah, A. (2015). Hubungan tingkat pengetahuan perawat dengan tindakan perawat dalam manajemen nyeri pasien post operasi di bangsal bedah RSUD dr.Soehadi Prijonegoro Sragen. Skripsi Terpublikasi. STIKes Kusuma Husada Surakarta. Diperoleh dari http://digilib.stikeskusumahusada.ac. id/

Setiyawati, R. (2013). Analisis praktik klinik keperawatan kesehatan masyarakat perkotaan pada pasisen kanker payudara pasca mastektomi di ruang rawat bedah gedung $A$ RSUPN Cipto Mangunkusumo Jakarta. Karya Ilmiah Akhir. Fakultas Ilmu Keperawatan Universitas Indonesia. Diperoleh dari http://lib.ui.ac.id

Simamora, Henry. (2006). Manajemen sumber daya manusia (Ed.3). Yogyakarta : bagian penerbitan STIE YKPN.

Siwu, L., Savitri, W., \& Hutasoit, M. (2014). Pendidikan kesehatan berpengaruh pada tingkat pengetahuan klien tentang perawatan pasca operasi kanker payudara. Media Ilmu Kesehatan. 3 (1), 29-35. STIKes Jenderal Ahmad Yani Yogyakarta.

Wahyudi., Iwan., Dewi, I., \& Sigit, M. (2010). Hubungan persepsi perawat tentang profesi keperawatan, kemampuan dan motivasi kerja terhadap kinerja perawat pelaksana di RSUD dr. Slamet Garut. Skripsi Terpublikasi. Fakultas Ilmu Keperawatan Universitas Indonesia. Diperoleh dari http://lib.ui.ac.id

Wawan, A., \& Dewi, M. (2010). Teori dan pengukuran : Pengetahuan, sikap dan perilaku manusia. Yogyakarta : Nuha Medika.

Yulia,S., Hamid A.Y.S., \& Mustikasari. (2012). Peningkatan pemahaman perawat pelaksana dalam penerapan keselamatan pasien melalui pelatihan keselamatan pasien. Jurnal Keperawatan Indonesia, 15 (3), 185192. 